\title{
Original Article \\ Spatial Zoning Strategy for Socio-Economic Development and Environmental Protection in Cu Chi District, Hochiminh City
}

\author{
Nguyen Huy Anh ${ }^{1, *}$, Nguyen Trinh Minh Anh ${ }^{2}$ \\ ${ }^{1}$ University of Natural Resources and Environment, Hochiminh city, 236B, Le Van Sy, \\ Tan Binh district, Hochiminh city, Vietnam \\ ${ }^{2}$ Nong Lam University, Hochiminh city, Linh Trung ward, Thu Duc district, Hochiminh city, Vietnam
}

Received 30 January 2020

Revised 04 March 2020; Accepted 10 March 2020

\begin{abstract}
Cu}$ Chi, with a natural area of 43,496ha, is a district in the northeast of Hochiminh city, where infrastructure has been built intensively and rapidly in recent years. This development results in not only general socio-economic conditions but also the improvement of local welfare. On the other hand, relentless urban and industrial development in $\mathrm{Cu}$ Chi district may potentially pose negative impact on general environmental condition due to reduction of green area and industrial waste discharge to the natural ecology. As a consequence, spatial planning and zoning are necessary to balance socio-economic progress and environmental protection for sustainable development. By analyzing the socio-economic, environment and remote sensing data using GIS technology, the research divides the district into 3 major environment zones, including 13 minor sub-zones. Meanwhile, the result also suggests 04 integrated socio-economic development and environmental protection zones as follows: environmental protection with 2 sub-zones (2,286 ha), environmental friendly development with 6 sub-zones $(27,753 \mathrm{ha})$, strengthened environmental management with 4 sub-zones (8,370 ha) and environmental recovery and rehabilitation with 1 sub-zone $(5,087 \mathrm{ha})$. The authors believe that the spatial zoning is important in providing the basis to develop a strategy for socio-economic development and environmental protection for each sub-zone.
\end{abstract}

Keywords: Environment planning protection, GIS, zoning, $\mathrm{Cu}$ Chi district.

\footnotetext{
* Corresponding author

E-mail address: anhnh@hcmunre.edu.vn

https://doi.org/10.25073/2588-1094/vnuees.4548
} 


\title{
Định hướng không gian phát triển kinh tế - xã hội và bảo vệ môi trường huyện Củ Chi, Thành phố Hồ Chí Minh
}

\author{
Nguyễn Huy Anh ${ }^{1 *}$, Nguyễn Trịnh Minh Anh ${ }^{2}$ \\ ${ }^{I}$ Trường Đại học Tài nguyên và Môi trường thành phố Hồ Chí Minh, 236B Lê Văn Sỹ, \\ thành phố Hồ Chi Minh, Việt Nam \\ ${ }^{2}$ Đại học Nông Lâm thành phố Hồ Chí Minh, Linh Trung, Thủ Đức, thành phố Hồ Chí Minh, Việt Nam \\ Nhận ngày 30 tháng 01 năm 2020 \\ Chỉnh sửa ngày 04 tháng 3 năm 2020; Chấp nhận đăng ngày 10 tháng 3 năm 2020
}

\begin{abstract}
Tóm tắt: Nằm về phía Tây Bắc của thành phố Hồ Chí Minh, huyện Củ Chi có diện tích tự nhiên 43.496ha. Trong những năm qua Củ Chi phát triển rất mạnh về hạ tầng, kinh tế - xã hội, góp phần quan trọng vào nâng cao đời sông vật chất và tinh thần của người dân. Mặt khác, quá trình phát triển kinh tế và công nghiệp của huyện Củ Chi tiềm ẩn những rủi ro về mặt môi trường do sự suy giảm nhanh chóng của diện tích cây xanh và quá trình xả thải công nghiệp. Chính vì vậy việc hoạch định không gian vừa phát triển kinh tề - xã hội, vừa bảo vệ môi trường, đáp ứng được mục tiêu phát triển bền vững trong tương lai là hết sức cấp thiết. Trên cơ sở phân tích tổng hợp điểu kiện tự nhiên, kinh tế - xã hội và môi trường nghiên cứu đã phân chia huyện Củ Chi thành 3 vùng môi trường và 13 tiểu vùng môi trường. Đồng thời kết quả nghiên cứu cũng đề xuất được 04 không gian phát triển kinh tế - xã hội và bảo vệ môi trường bao gồm: Không gian bảo vệ, bảo tồn có 2 tiểu vùng với diện tích 2.286 ha, không gian phát triển thân thiện với môi trường 6 tiểu vùng với diện tích $27.753,16$ ha, không gian tăng cường các biện pháp quản lý môi trường có 4 tiểu vùng với diện tích là 8.370 .21 ha, không gian cải tạo và phục hồi môi trường có 1 tiểu vùng với diện tích là 5.087,24 ha. Đây là cơ cơ sở khoa học quan trọng giúp cho các nhà hoạch định chính sách đưa ra chiến lược phát triển huyện Củ Chi theo hướng bền vững trong tương lai.
\end{abstract}

Tù khoá: quy hoạch bảo vệ môi trường, GIS, phân vùng, huyện Củ Chi.

\section{Mở đầu}

Trong những năm gần đây tốc độ phát triển về đô thị, công nghiệp không chỉ diễn ra tại các quận nội thành mà còn đang diễn ra nhanh tại các quận huyện ngoại thành, trong đó có huyện $\mathrm{Củ}$ Chi. Nằm về phía Tây Bắc của thành phố Hồ Chí Minh, huyện Củ Chi có diện tích tự nhiên

\footnotetext{
*Tác giả liên hệ.

Địa chỉ email: anhnh@hcmunre.edu.vn
}

https://doi.org/10.25073/2588-1094/vnuees.4548 43.496ha [1], phía Bắc giáp huyện Trảng Bàng tỉnh Tây Ninh, phía Đông - Đông Bắc giáp huyện Bến Cát - tỉnh Bình Dương, phía Tây và Tây Nam giáp huyện Đức Hòa - tỉnh Long An, phía Nam giáp huyện Hóc Môn. Trong những năm qua huyện Củ Chi phát triển rất mạnh về hạ tầng kinh tế - xã hội, góp phần quan trọng vào nâng cao đời sống vật chât và tinh thần của người dân 
trên địa bàn huyện. Hệ thống giao thông phát triển mạnh, nhiều khu công nghiệp được đầu tư xây dựng, cơ sở y tế, giáo dục được đầu tư,... Nhiều dự án quy mô lớn của thành phố được quy hoạch trên địa bàn huyện, bao gồm dự án Khu đô thị Tây - Bắc thành phố, dự án phát triển du lịch sinh thái - nhà vườn ven sông Sài Gòn, đề án quy hoạch sản xuất nông nghiệp thành phố đến năm 2020, tầm nhìn đến năm 2025,... [1]. Hiện nay, trên địa bàn huyện Củ Chi đã có nhiều quy hoạch phát triển như: quy hoạch sử dụng đất đến năm 2020 và định hướng đến năm 2025, Quy hoạch chung huyện Củ Chi đến năm 2020,... Ngoài ra trên địa bàn huyện cũng có nhiều quy hoạch liên quan đến địa bàn thành phố Hồ Chí Minh như: quy hoạch phát triển giao thông, quy hoạch phát triển đồ thị,... Mặc dù có nhiều quy hoạch nhưng chủ yếu là các quy hoạch đơn ngành chưa có quy hoạch mang tính tổng hợp - vừa đáp ứng được mục tiêu phát triển kinh tế - xã hội vừa bảo vệ được môi trường và có khả năng ứng phó với điều kiện biến đồi khí hậu. Chính vì vậy, việc đánh giá tổng hợp các điều kiện tự nhiên, kinh tế - xã hội và môi trường làm cơ sở cho hoạch định không gian vừa phát triển kinh tế - xã hội, vừa bảo vệ môi trường đáp ứng được mục tiêu phát triển bền vững trong tương lai ở địa bàn huyện Củ Chi là hết sức cấp thiết.

Trong những năm gần đây, việc nghiên cứu xây dựng quy hoạch bảo vệ môi trường (QHBVMT) cho định hướng phát triển bền vững lãnh thổ đã được chú trọng ở Việt Nam, bằng chứng là hướng nghiên cứu này đã được các nhà khoa học, các cơ quan, tổ chức quan tâm trên địa bàn cả nước. Trước năm 2014, khái niệm về QHBVMT ở Việt Nam hầu như vẫn chưa được thống nhất. Thuật ngữ Quy hoạch bảo vệ môi truoòng đã được đề cập tại Điều 50, chương IV của Luật Bảo vệ môi trường năm 2005. Đến năm 2008 tác giả Nguyễn Cao Huần đã nhấn mạnh thêm nhiệm vụ và nội dung của QHBVMT dưới góc nhìn của nhà Địa lý: QHBVMT là một trong nhũng nhiệm vu quan trọng cho sự phát triển bền vững lãnh thố, là một phần của chiến lược phát triển kinh tế, xã họi $(K T-X H)$ thân thiện với môi truờng. QHBVMT nhằm giải quyết mâu thuẫn giữa bảo vệ môi truờng và phát triển của tùng vùng [2]. QHBVMT có thể tạo ra những nền tảng để xem xét và điều chỉnh quy hoạch kinh tế trước đó cho lãnh thổ. Đến năm 2014, trong Luật BVMT đã đưa ra giải thích về thuật ngữ QHBVMT như sau: QHBVMT là việc phân vùng môi trường để bảo tồn, phát triển và thiết lập hệ thống ha tầng kỹ thuật bảo vệ môi truoòng gẳn với hệ thống giải pháp bảo vệ môi truờng trong mối liên quan chăt chẽ với quy hoạch phát triển KT-XH nhằm phát triển bền vũng [3] khái niệm này cũng được sử dụng trong quá trình nghiên cứu.

Trong những năm gần đây QHBVMT đã được chú trọng nghiên cứu và được xem như một công cụ hữu hiệu trong công tác quản lý và bảo vệ môi trường ở các địa phương. Phương pháp áp dụng chính là dựa trên việc đánh giá tổng hợp các điều kiện tự nhiên, kinh tế - xã hội và môi trường tiến hành phân vùng môi trường và đề xuất QHBVMT Dựa vào các tiêu chí chính như: Tính đồng nhất tương đối về điều kiện tự nhiên (Địa chất-địa mạo, Khí hậu-thủy văn, Đất-thực vật); Tính đặc thù về phát triển kinh tế, khai thác, sử dụng tài nguyên (khai thác khoáng sản, các loại hình sử dụng đất, mức độ đô thị hóa và phát triển công nghiệp, nông thôn và phát triển nông nghiệp, lâm nghiệp và ngư nghiệp); Tập hợp các vấn đề bức xúc về môi trường và tai biến thiên nhiên [2]. Phân vùng môi trường phục vụ quản lý môi trường cấp huyện dựa trên việc đánh giá tổng hợp điều kiện tự nhiên, xã hội và môi trường xác định các tiểu vùng môi trường làm cơ sở cho việc hoạch định chiến lược phát triển kinh tế - xã hội và bảo vệ môi trường bền vững $[4,5]$.

Hiện nay có một số tỉnh cũng đã xây dựng và phê duyệt QHBVMT cấp tỉnh như: An Giang, Hà Nam, Cao Bằng, Thanh Hóa, Kon Tum, Hà Nội, thành phố Hồ Chí Minh, Thái Nguyên, Nghệ An, Hải Dương, Quảng Trị, Quảng Ninh, Bến Tre,... đã xây dựng QHBVMT cho quy mô toàn tỉnh. Tất cả các QHBVMT ở các tỉnh đều xác định phân vùng môi trường dựa trên các yếu tố tự nhiên, kinh tế-xã hội, môi trường sau đó tiến hành đề xuất không gian phát triển kinh tế - xã hội và bảo vệ môi trường theo hướng bền vững.

Về phương pháp áp dụng trong nghiên cứu định hướng không gian phát triển kinh tế -xã hội 
và bảo vệ môi trường chủ yếu là phân vùng môi trường dựa trên việc đánh giá tổng hợp các yếu tố tự nhiên, kinh tế - xã hội và môi trường [2,6,7]. Với hướng tiếp cận địa lý, với quan niệm các đối tượng phải được thể hiện trong không gian và được xem xét biến đổi theo thời gian. Để phục vụ xây dựng bản đồ định hướng không gian phát triển kinh tế - xã hội và bảo vệ môi trường huyện Củ Chi nghiên cứu đã lựa chọn phương pháp phân kiểu lãnh thổ dựa theo đặc điểm của các yếu tố tự nhiên, kết hợp với những đặc trưng về kinh tế, xã hội, nhân văn. Phân kiểu lãnh thổ là chia lãnh thổ thành các đơn vị, mỗi đơn vị lãnh thổ có những đặc điểm riêng, không giống với đơn vị liền kề. Kiểu lãnh thổ có tính lặp lại trong không gian. Phân kiểu lãnh thổ thường được áp dụng để phân chia lãnh thổ theo các yếu tố tự nhiên và theo các dạng tài nguyên cho mục đích khai thác, sử dụng trong các ngành kinh tế và hoạt động nhân sinh.

\section{Phương pháp và dữ liệu}

\subsection{Khu vục nghiên cứu}

a. Vị trí: huyện Củ Chi có vị trí ở phía Tây Bắc thành phố Hồ Chí Minh, toạ độ địa lý từ $10^{\circ} 53^{\prime} 00^{\prime}$ " đến $10^{\circ} 10^{\prime} 00^{\prime \prime}$ vĩ độ Bắc và từ $106^{0} 21^{\prime} 00^{\prime \prime}$ đến 106²40'00" kinh độ Đông, với 20 xã và 1 thị trấn. Địa giới hành chính của huyện được xác định: phía Bắc giáp huyện Trảng Bàng, tỉnh Tây Ninh; phía Đông giáp tỉnh Bình Dương; phía Nam giáp huyện Hóc Môn, thành phố Hồ Chí Minh; phía Tây giáp tỉnh Long An.

b. Cấu trúc địa hình có 3 dạng chính:

+ Vùng đồi gò: cao độ $10 \mathrm{~m}$ - $15 \mathrm{~m}$ tập trung ở phía Bắc huyện, gồm các xã Phú Mỹ Hưng, An Nhơn Tây, Nhuận Đức.

+ Vùng triền: chuyển tiếp giữa các vùng đồi gò và vùng bưng trũng có độ cao từ $5 \mathrm{~m}-10 \mathrm{~m}$ phân bố trên hầu hết các xã (xem Hình 1).

+ Vùng bưng trũng: cao độ từ $0,5-2 \mathrm{~m}$, tập trung ở các xã phía Nam, Tây Nam và ven sông Sài Gòn (xã Bình Mỹ, Trung An,...).

c. Khí hậu: Củ Chi nằm trong vùng khí hậu nhiệt đới gió mùa, mang tính chất cận xích đạo.
Trong năm có 2 mùa rõ rệt, mùa mưa từ tháng 5 đến tháng 11 , mùa khô từ tháng 12 đến tháng 4 năm sau, với đặc điểm chính:

+ Nhiệt độ tương đối ổn định, cao đều trong năm, trung bình năm khoảng $26,6^{\circ} \mathrm{C}$. Nhiệt độ trung bình tháng cao nhất là $28,8^{\circ} \mathrm{C}$ (tháng 4 ), nhiệt độ trung bình tháng thấp nhất $24,8^{\circ} \mathrm{C}$ (tháng 12). Tuy nhiên biên độ nhiệt độ giữa ngày và đêm chênh lệch khá lớn, vào mùa khô có trị số 8- $10^{\circ} \mathrm{C}[1]$.

+ Độ ẩm không khí trung bình năm khá cao $79,5 \%$, cao nhất vào các tháng $7,8,9$ là $80 \%$ $90 \%$, thấp nhất vào tháng 12 , là $70 \%$ [1] .

Mùa mưa bắt đầu từ tháng 5 kéo dài đến tháng 11 , mùa khô kéo dài từ cuối tháng 11 đến đầu tháng 5 năm sau. Trong mùa khô, hướng gió chủ yếu trong nữa đầu mùa Bắc- Đông Bắc, nữa cuối mùa chuyển sang hướng Đông- Đông Nam. Trong mùa mưa gió chủ yếu là gió mùa Tây Nam thịnh hành từ cuối tháng 5 đến đầu tháng 8 .

d. Thủy văn: đặc điểm chính thủy văn ở địa bàn huyện Củ Chi:

+ Sông Sài Gòn là sông lớn nhất trong địa bàn huyện, chay theo hướng Tây Bắc- Đông

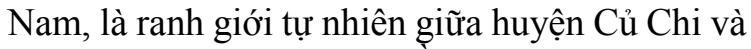
tỉnh Bình Dương với chiều dài qua huyện là $45 \mathrm{~km}$. Chiều rộng trung bình của sông (đoạn trung lưu): $200 \mathrm{~m}$, độ sâu $16 \mathrm{~m}$. Lưu lượng sông Sài Gòn thay đổi theo mùa, thường mùa mưa lớn hơn 1 - 5 lần mùa khô.

+ Kênh Bến Mương-Láng Thé: hệ thống gồm rạch Bến Mương-Láng Thé nối ra sông Sài Gòn tại Phú Mỹ Hưng và một kênh tướitiêu nối Láng Thé với Rạch Tra, với tổng chiều dài 32 $\mathrm{km}$, độ rộng từ 30-50 m. Hệ thống này chủ yếu làm nhiệm vụ tưới kết hợp tiêu cho vùng ven sông Sài Gòn của huyện Củ Chi và Bắc Hóc Môn.

+ Kênh Thầy Cai dài $24 \mathrm{~km}$, rộng $45 \mathrm{~m}$, sâu $3 \mathrm{~m}$ là con kênh lớn nằm phía Tây Nam huyện, là ranh giới giữa huyện Củ Chi và huyện Đức Hòa tỉnh Long An. Kênh Thầy Cai nối rạch Trảng Bàng (tỉnh Tây Ninh) với sông Vàm Cỏ Đông, thông với rạch Tra qua kênh An Hạ. Ngoài ra Củ Chi còn có nhiều kênh rạch nhỏ nằm ven sông Sài Gòn như: rạch Bà Phước, rạch Dừa,... 


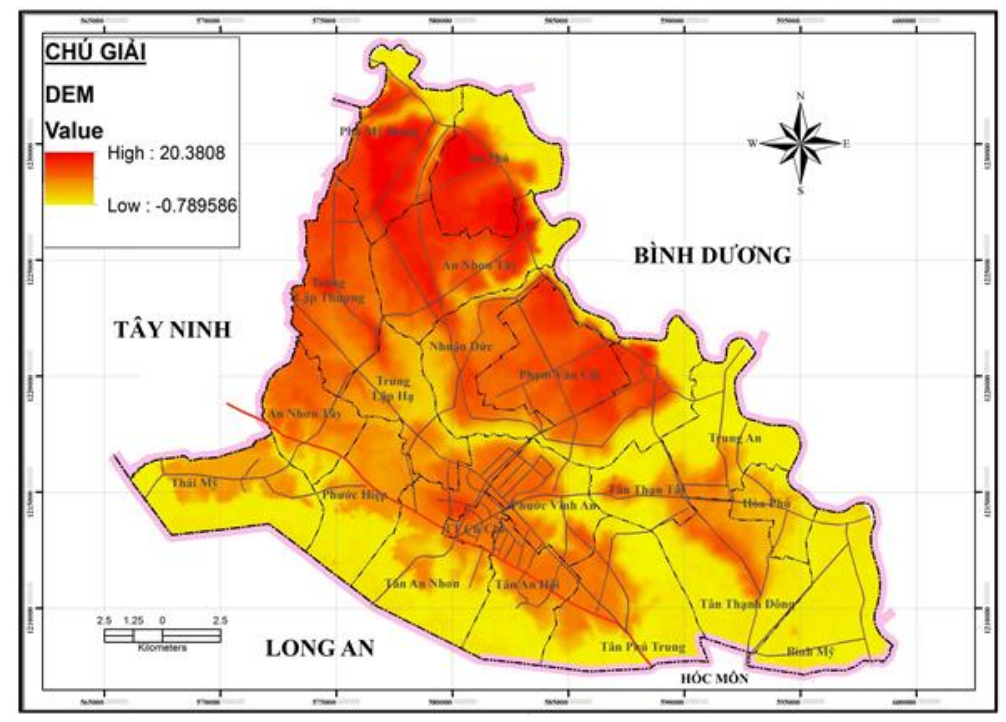

Hình 1. Độ cao địa hình huyện Củ Chi.

e. Đặc điểm lớp phủ thực vật

Việc phân tích đánh giá đặc điểm lớp phủ phục vụ cho phân vùng không gian phát triển kinh tế - xã hội và bảo vệ môi trường ở địa bàn huyện Củ Chi là rất quan trọng. Ngoài việc sử dụng dữ liệu hiện trạng sử dụng đất năm 2015, nghiên cứu này có sử dụng ảnh vệ tinh Landsat 8 với độ phân giải $30 \mathrm{~m}$, với mục đích cập nhật, phân tích thay đổi ở những loại lớp phủ có tính biến động cao ở địa bàn như: thảm cây nông nông nghiệp, đô thị, công nghiệp. Mặc dù có độ phân giải không cao, nhưng trong điề̀u kiện kinh phí hạn hẹp, thời gian ngắn thì việc sử dụng ảnh Landsat 8 để cập nhật đặc điểm lớp phủ trên địa bàn cấp huyện vẫn có thể chấp nhận được.

Dữ liệu ảnh Landsat 8 với độ phân giải $30 \mathrm{~m}$ được lấy từ trang web https://earthexplorer.usgs. gov/ với Path/Row: 125/49. Ảnh được chụp ngày 12/02/2017 với 11 kênh phổ, có mã ảnh là LC81250522017045LGN00, chất lượng ảnh tốt (9/10), độ mây che phủ $0,51 \%$. Để tăng độ chính xác cũng như tính khoa học, nghiên cứu chọn phương pháp phân loại có kiểm định. Cụ thể là phân loại gần đúng nhất (Maximum Likelihood Classifier - MLC).

Trong quá trình giải đoán ảnh sử dụng chỉ số Kappa $(\mathrm{K})$ nhằm thống kê, kiểm tra và đánh giá sự phù hợp giữa những nguồn dữ liệu khác nhau hoặc khi áp dụng các thuật toán khác nhau. Cách xác định chỉ số Kappa được thể hiện như công thức 1:

$$
K=\frac{(T-E)}{(1-E)}
$$

Trong đó:

- T-Độ chính xác toàn cục cho bởi ma trận sai số.

- E- đại luợng thể hiện sụ mong muốn (kỳ vọng) phân loại chinh xác có thể dụ đoán trước, nghĩa là E góp phần uớc tính khả năng phân loại chính xác trong quá trình phân loại thực sụ. Khi $K=1$, độ chính xác phân loại là tuyệt đối.

Kết quả đánh giá độ chính xác ở địa bàn huyện Củ Chi cho giá trị Kappa = 0,7485, ở mức trung bình, nhưng có thể châp nhận được.

Trên cơ sở phân tích ảnh vệ tinh Landsat 8 (2017) kết hợp với bản đồ hiện trạng sử dụng đất năm 2015, bài báo đã phân chia địa bàn huyện Củ Chi thành 9 loại lớp phủ thực vật chính là rừng tự nhiên, cao su, khu dân cư, lúa và hoa màu, đồng cỏ và thảm cây bụi thứ sinh, rừng trồng, mặt nước, khu công nghiệp và đất trống. Trong đó đất khu dân cư có diện tích lớn nhất $10.025,28$ ha chiếm $23,06 \%$, tiếp đến là kiểu lớp phủ là đồng cỏ - trảng cây bụi diện tích $8.825,38 \%$ chiếm $20,3 \%$, rừng tự nhiên phân bố chủ yếu ở khu vực địa đạo Củ Chi và là loại lớp phủ có diện tích nhỏ nhất 143,45ha chiếm $0,32 \%$ (xem Hình 2). 


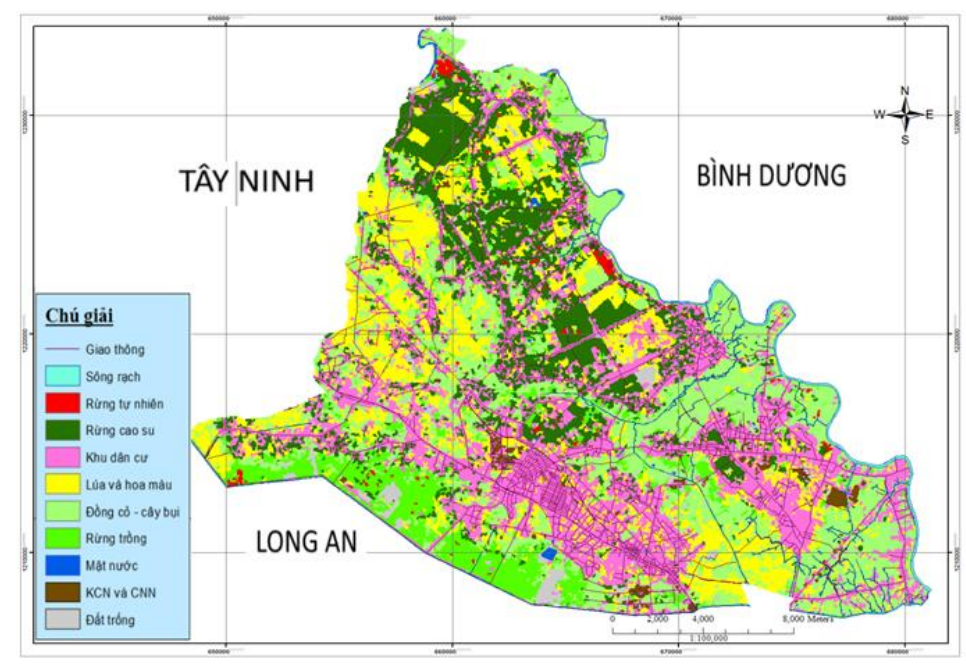

Hình 2. Hiện trạng lớp phủ.

Bảng 1. Thống kê diện tích các loại lớp phủ

\begin{tabular}{llrr}
\hline TT & Tên lớp phủ & \multicolumn{1}{c}{$\begin{array}{c}\text { Diện tích } \\
\text { (ha) }\end{array}$} & \multicolumn{1}{c}{$\begin{array}{c}\text { Tỷ lệ } \\
(\%)\end{array}$} \\
\hline 1 & Rừng tự nhiên & 140,45 & 0,32 \\
2 & Rừng cao su & 7968,70 & 18,33 \\
3 & Khu dân cư & 10025,28 & 23,06 \\
4 & Lúa - hoa màu & 8532,54 & 19,62 \\
5 & Đồng cỏ - rừng & & \\
& cây bụi thứ sinh & 8825,38 & 20,30 \\
6 & Rừng trồng & 5032,95 & 11,58 \\
7 & Mặt nước & 943,66 & 2,17 \\
8 & Khu công & & \\
& nghiệp - cụm & & \\
& công nghiệp & 764,71 & 1,76 \\
9 & Đất trống & 1243,51 & 2,86 \\
& Tổng diện tích & & \\
& đất tự nhiên & 43477,18 & 100 \\
\hline
\end{tabular}

\subsection{Phương pháp nghiên cúu}

a. Phương pháp nghiên cứu

Phuơng pháp ứng dụng GIS và viễn thám: Đây là bộ phương pháp quan trọng và mang lại hiệu quả rất cao trong quá trình nghiên cứu phân vùng không gian phát triển $\mathrm{KT}-\mathrm{XH}$ và bảo vệ môi trường.

Dựa trên các dữ liệu đã thu thập như bản đồ nền, bản đồ thổ nhưỡng, bản đồ hiện trạng sử dụng đất, sử dụng phần mềm GIS (mapinfo, arcGIS) để chuẩn hóa dữ liệu về cùng định dạng, cấu trúc dữ liệu, hệ tọa độ, tỷ lệ. Ngoài ra, phương pháp chồng xếp bản đồ trong GIS hỗ trợ nghiên cứu xây dựng được bản đồ phân vùng lãnh thổ và bản đồ định hướng không gian phát triển kinh tế xã hội và bảo vệ môi trường. Đồng thời GIS cũng giúp thống kê diện tích các vùng, tiểu vùng theo từng loại không gian đề xuất.

Phương pháp ứng dụng viễn thám ở nghiên cứu này được sử dụng trong quá trình phân tích đánh giá đặc điểm thảm thực vật ở địa bàn huyện Củ Chi. Trong bài báo này sử dụng ảnh vệ tỉnh Landsat 8, chụp ngày 14/2/2017 với độ phân giải $30 \mathrm{~m}$. Ảnh vệ tinh sau khi thu thập được xử lý, lấy mẫu phân tích (213 mẫu), sử dụng phương pháp giải đoán có kiểm định (Maximum Likelihood Classifier) và 45 mẫu kiểm chứng sau khi giải đoán. Kết quả giải đoán ảnh viễn thám được kết hợp với dữ liệu hiện trạng sử dụng đất huyện Củ Chi để xây dựng bản đồ lớp phủ.

Phương pháp phân vùng lãnh thổ: Có thể hiểu đơn giản là phân vùng lãnh thổ là phân chia lãnh thổ thành những đơn vị lãnh thổ nhỏ hơn. Phân vùng lãnh thổ ở huyện Củ Chi thực chất là phân chia lãnh thổ này thành các vùng và tiểu vùng với những đặc trưng riêng về tự nhiên. Từ các đơn vị tiểu vùng sẽ phân tích các chức năng lãnh thổ, đây là cơ sở khoa học cho việc và hoạch định không gian phát triển kinh tế gắn với việc khai thác, sử dụng hợp lý tài nguyên và bảo vệ môi trường theo hướng phát triển bền vững. 


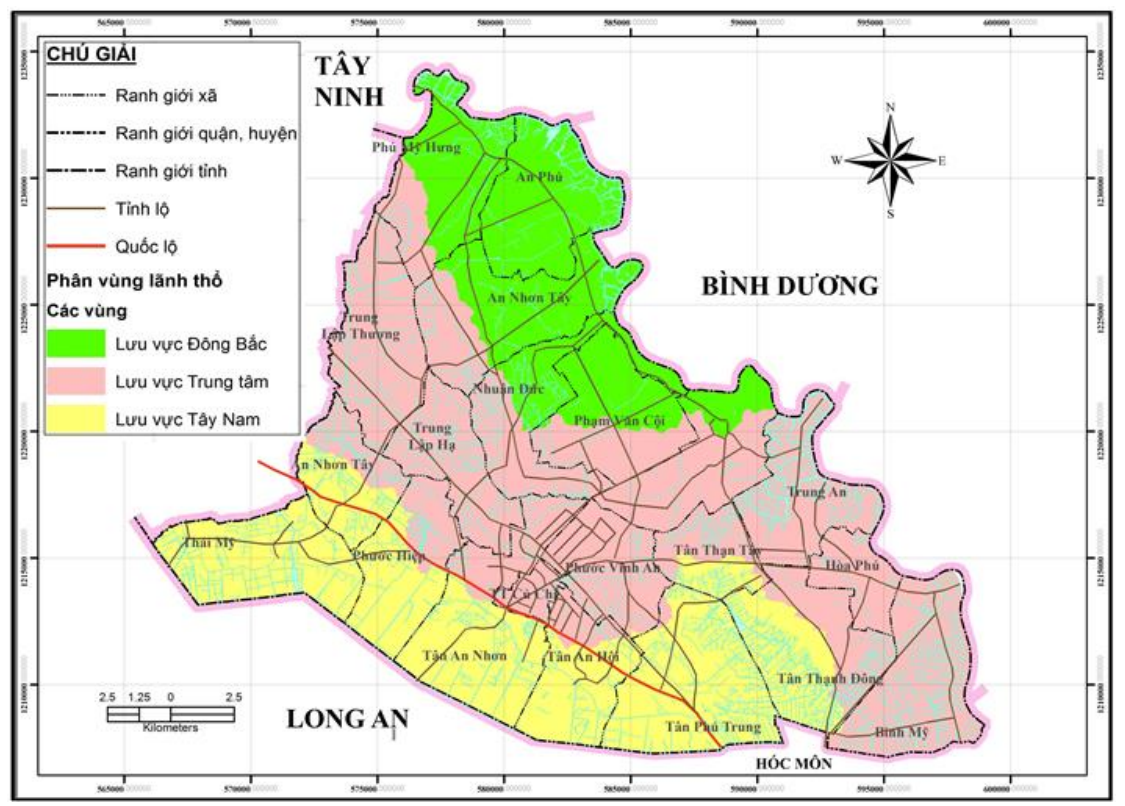

Hình 3. Các lưu vực.

Tiếp cận theo lưu vực: lưu vực sông là vùng đất mà trong phạm vi đó nước mặt, nước dưới đất chảy tự nhiên vào sông và thoát ra một cửa chung hoặc thoát ra biển. Lưu vực sông gồm có lưu vực sông liên tỉnh và lưu vực sông nội tỉnh (Luật Tài nguyên nước năm 2012). Trong nghiên cứu này, giai đoạn phân cấp vùng sử dụng cách tiếp cận theo lưu vực để phân chia lãnh thổ nghiên cứu. Theo đó huyện Củ Chi được chia thành 3 lưu vực (vùng) chính là lưu vực Đông Bắc (ký hiệu: A), lưu vực trung tâm (ký hiệu: B), lưu vực Tây Nam (ký hiệu: $\mathrm{C}$ ). Kết hợp với việc phân tích các yếu tố hiện trạng môi trường, kinh tế xã hội, điều kiện thổ nhưỡng, hiện trạng lớp phủ,... để phân chia ra các đơn vị tiểu vùng nhỏ hơn, có tính đồng nhất và chức ăng rõ ràng hơn.

Để phục vụ QHBVMT huyện Củ Chi, lựa chọn cách phân kiểu lãnh thổ dựa theo đặc điểm của các yếu tố tự nhiên, kết hợp với những đặc trưng về KT-XH, nhân văn. Từ phân tích các bước phân vùng môi trường của các công trình nghiên cứu đã được công bố $[4,6,8]$ nghiên cứu đã xây dựng được các bước thực hiện nghiên cứu phân vùng môi trường cho đơn vị cấp huyện và áp dụng vào địa bàn huyện Củ Chi. Theo đó cấp phân vị trong phân vùng môi trường của đơn vị cấp huyện Củ Chi bao gồm 2 cấp là: lưu vực (gọi là cấp vùng môi trường) và cấp tiểu vùng môi trường.

\subsection{Dũ liệu nghiên cứu}

- Dữ liệu ảnh vệ tinh: nghiên cứu sử dụng ảnh vệ tinh Landsat 8 (NASA) với độ phân giải $30 \mathrm{~m}$ được lấy từ trang web https://earthexplorer. usgs.gov/ với Path/Row: 125/49. Ảnh được chụp ngày 12/02/2017 với 11 kênh phổ, có mã ảnh là LC81250522017045LGN00, chất lượng ảnh tốt (9/10), độ mây che phủ 0,51\%. Kết quả phân tích ảnh hỗ trợ cập nhật bản đồ hiện trạng lớp phủ.

- Dữ liệu bản đồ: bản đồ được sử dụng trong bài báo là:

+ Bản đồ nền tỷ lệ 1: 25000 thành phố Hồ Chí Minh, hệ tọa độ VN2000.

+ Bản đồ hiện trạng sử dụng đất năm 2015, tỷ lệ 1: 25000, hệ tọa độ VN2000

+ Bản đồ thổ nhưỡng thành phố Hồ Chí Minh tỷ lệ 1: 50 000, Hệ tọa độ VN2000.

Tất cả bản đồ được hiệu chỉnh, đưa về cùng hệ tọa độ và định dạng dữ liệu để sử dụng cho các phần mềm GIS trong phân tích và xây dựng các bản đồ chuyên đề phục vụ cho nghiên cứu. 


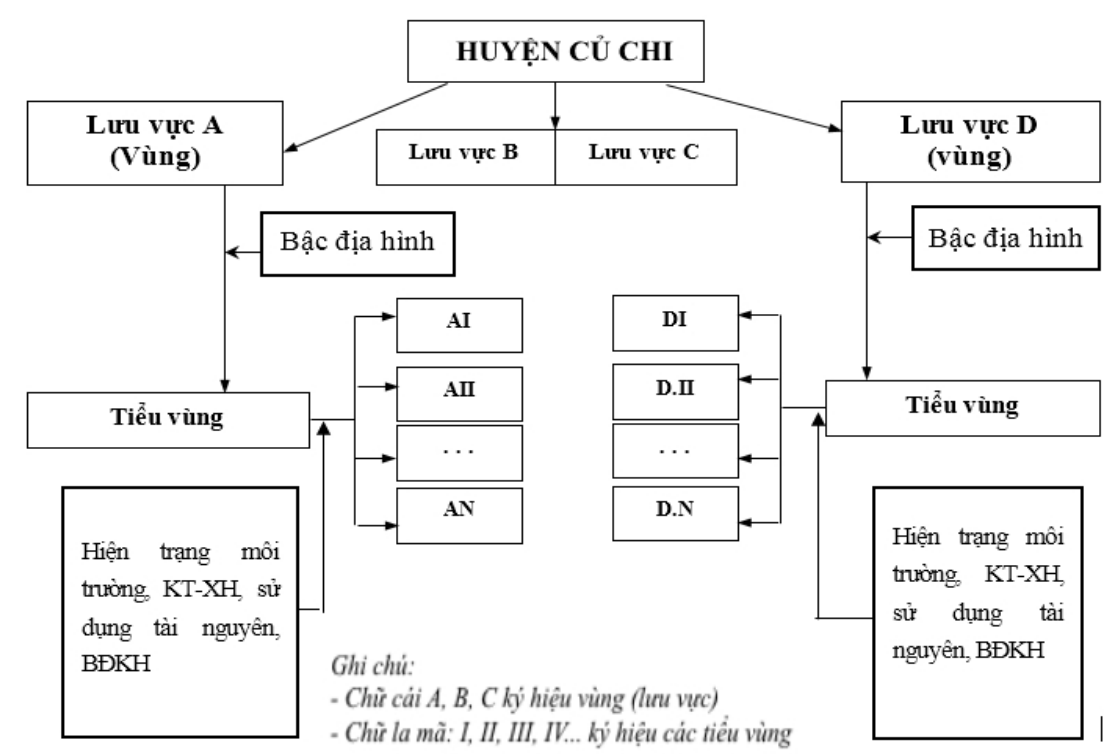

Hình 4. Sơ đồ quy trình phân vùng.

\section{Kết quả và thảo luận}

\subsection{Các tiểu vùng môi trường}

Để đề xuất không gian phát triển kinh tế - xã hội và bảo vệ môi trường một vùng lãnh thổ, cần phải tiến hành phân vùng môi trường (PVMT). Mục đích là tạo dựng cơ sở khoa học để điều hòa sự phát triển của hệ thống tài nguyên - môi trường-KT-XH đang tồn tại và phát triển trong vùng, đảm bảo sao cho sự phát triển của hệ thống KT-XH phù hợp với khả năng chịu tải của môi trường tự nhiên, bảo vệ được môi trường sống và làm cho chất lượng cuộc sống ngày càng tốt hơn.

Từ kết quả phân tích tổng hợp các yếu tố thành phần đã phân chia huyện Củ Chi thành 3 vùng môi trường: vùng môi trường phía Đông Bắc, vùng môi trường trung tâm, vùng môi trường phía Tây Nam; 13 tiểu vùng môi trường. Trên cơ sở phân tích điều kiện KT-XH, trong mối quan hệ với điều kiện tự nhiên, môi trường. Đó là các không gian phát triển kinh tế, đồng thời cũng là các không gian được đề xuất định hướng bảo vệ môi trường ở các dạng và mức độ khác nhau (Bảng 2).
Bảng 2. Các tiểu vùng môi trường

\begin{tabular}{|c|c|c|}
\hline Vùng & Tiểu vùng & Diện tích (ha) \\
\hline \multirow{5}{*}{$\begin{array}{l}\text { Vùng môi } \\
\text { trường } \\
\text { phía Đông } \\
\text { Bắc } \\
\text { (A) }\end{array}$} & $\begin{array}{l}\text { Tiểu vùng môi trường gò đồi } \\
\text { Phú Mỹ Hưng (A.I) }\end{array}$ & 937,50 \\
\hline & $\begin{array}{l}\text { Tiểu vùng Môi trường An } \\
\text { Nhơn Tây (A.II) }\end{array}$ & $1.510,09$ \\
\hline & $\begin{array}{l}\text { Tiểu vùng môi trường An } \\
\text { Phú (A.III) }\end{array}$ & $1.889,21$ \\
\hline & $\begin{array}{l}\text { Tiểu vùng môi trường Phạm } \\
\text { Văn Cội (A.IV) }\end{array}$ & $3.263,69$ \\
\hline & $\begin{array}{l}\text { Tiểu vùng môi trường khu } \\
\text { vực Phú Hòa Đông (A.V) }\end{array}$ & $1.348,50$ \\
\hline \multirow{5}{*}{$\begin{array}{l}\text { Vùng môi } \\
\text { trường } \\
\text { trung tâm } \\
\text { Củ Chi } \\
\text { (B) }\end{array}$} & $\begin{array}{l}\text { Tiêu vùng môi trường thung } \\
\text { lũng trung tâm Củ Chi (B.I) }\end{array}$ & $13.036,65$ \\
\hline & $\begin{array}{l}\text { Tiêu vùng môi trường khu } \\
\text { vực Trung An (B.II) }\end{array}$ & $1.005,51$ \\
\hline & $\begin{array}{l}\text { Tiểu vùng môi trường khu } \\
\text { vực thấp trũng Tân Thạnh } \\
\text { Đông (B.III) }\end{array}$ & $1.928,27$ \\
\hline & $\begin{array}{l}\text { Tiểu vùng môi trường khu } \\
\text { vực Bình Mỹ (B.IV) }\end{array}$ & $2.249,28$ \\
\hline & $\begin{array}{l}\text { Tiểu vùng môi trường đô thị } \\
\text { hành chính thị trấn Củ Chi } \\
\text { (B.V) }\end{array}$ & $3.230,21$ \\
\hline \multirow{3}{*}{$\begin{array}{l}\text { Tiểu vùng } \\
\text { môi trường } \\
\text { Tây Nam } \\
\text { (C) }\end{array}$} & $\begin{array}{l}\text { Tiểu vùng môi trường khu } \\
\text { vực Thái Mỹ - Phước Hiệp } \\
\text { (C.I) }\end{array}$ & 5087,24 \\
\hline & $\begin{array}{l}\text { Tiêu vùng môi trường khu } \\
\text { vực Phước Thạnh - Tân An } \\
\text { Hội (C.II) }\end{array}$ & $4.744,49$ \\
\hline & $\begin{array}{l}\text { Tiểu vùng môi trường khu } \\
\text { vực Tân Phú Trung (C.III) }\end{array}$ & $3.273,58$ \\
\hline
\end{tabular}




\section{2. Đề xuất không gian phát triển KT-XH và bảo vệ môi trường}

Trên cơ sở phân vùng môi trường và cách tiếp cận, phương pháp, quy trình nghiên cứu được trình bày ở trên (Hình 4), huyện Củ Chi được phân chia theo 4 không gian như sau:

a. Không gian bảo vệ, bảo tồn

Không gian bảo vệ bảo tồn có diện tích 2.286 ha, chiếm $5,27 \%$ diện tích tự nhiên lãnh thổ huyện Củ Chi, phân bố ở 2 khu vực chính là xã Phú Mỹ Hưng và xã Phạm Văn Cội. Không gian BVBT được chia thành 2 tiểu vùng là: Tiểu vùng môi trường vùng gò đồi Phú Mỹ Hưng (A.I) và Tiểu vùng môi trường Phú Hòa Đông (A.V).

b. Không gian phát triển thân thiện với môi trường

Đây là không gian lớn nhất, với 6 tiểu vùng có diện tích $27.753,16$ ha chiếm $63,80 \%$ tổng diện tích tự nhiên toàn huyện bao gồm: Tiểu vùng An Nhơn Tây (A.II); Tiểu vùng Phạm Văn Cội (IV); Tiểu vùng môi trường thung lũng trung tâm Củ Chi (B.I); Tiểu vùng khu vực thấp trũng Tân Thạnh Đông (B.III); Tiểu vùng khu vực Phước Thạnh-Phước Hiệp (C.II); Tiểu vùng khu vực Tân Phú Trung - Phước Vĩnh An (C.III). Với chức năng chính là: cung cấp không gian sống, nguồn nguyên liệu sạch, lương thực, thực phẩm đảm bảo an ninh lương thực và nguyên liệu cho sản xuất công nghiệp, nông nghiệp, hình thành cụm công nghiệp mới ưu tiên lắp đặt các thiết bị máy móc và ngành nghề sản xuất thân thiện với môi trường (xem thêm bản đồ).
Bảng 3. Không gian phát triển KT-XH và bảo vệ môi trường huyện $\mathrm{Củ} \mathrm{Chi}$

\begin{tabular}{|c|c|c|c|c|}
\hline TT & $\begin{array}{c}\text { Định hướng } \\
\text { QHBVMT }\end{array}$ & $\begin{array}{c}\text { Các } \\
\text { TVMT }\end{array}$ & $\begin{array}{l}\text { Diện tích } \\
(\mathrm{Ha})\end{array}$ & $\begin{array}{c}\text { Tỷ lệ } \\
(\%)\end{array}$ \\
\hline 1 & $\begin{array}{l}\text { Không gian } \\
\text { bảo vệ, bảo tồn }\end{array}$ & A.I, A.V & $2.286,00$ & 5,27 \\
\hline 2 & $\begin{array}{l}\text { Không gian } \\
\text { phát triển thân } \\
\text { thiện với môi } \\
\text { trường }\end{array}$ & $\begin{array}{l}\text { A.II, } \\
\text { A.IV, B.I, } \\
\text { BIII, C.II, } \\
\text { C.III }\end{array}$ & $27.753,16$ & 63,80 \\
\hline 3 & $\begin{array}{l}\text { Không gian } \\
\text { tăng cường các } \\
\text { biện pháp quản } \\
\text { lý môi trường }\end{array}$ & $\begin{array}{l}\text { A.III, } \\
\text { B.II, } \\
\text { B.IV, } \\
\text { B.V, }\end{array}$ & 8.370 .21 & 19,24 \\
\hline 4 & $\begin{array}{l}\text { Không gian cải } \\
\text { tạo và phục hồi } \\
\text { môi trường }\end{array}$ & C.I & $5.087,24$ & 11,69 \\
\hline & Tổng & & $43.496,58$ & 100 \\
\hline
\end{tabular}

Định hướng không gian phát triển kinh tế xã hội và bảo vệ môi trường: thực hiện đánh giá tác động môi trường chiến lược, đánh giá tác động môi trường cho các dự án quy hoạch phát triển đô thị, xây dựng đô thi hiện đại, đồng bộ hướng tới đô thị thông minh. Hoàn thiện hệ thống xử lý nước thải sinh hoạt. Sử dụng phân bón và hóa chất bảo vệ thực vật hợp lý, phát triển khu vực trồng cây ăn quả kết hợp tạo vành đai xanh tại các tiểu vùng dọc theo sông Sài Gòn. Quy hoạch cảnh báo nguy cơ ngập lụt đối với các Tiểu vùng ven sông Sài Gòn.

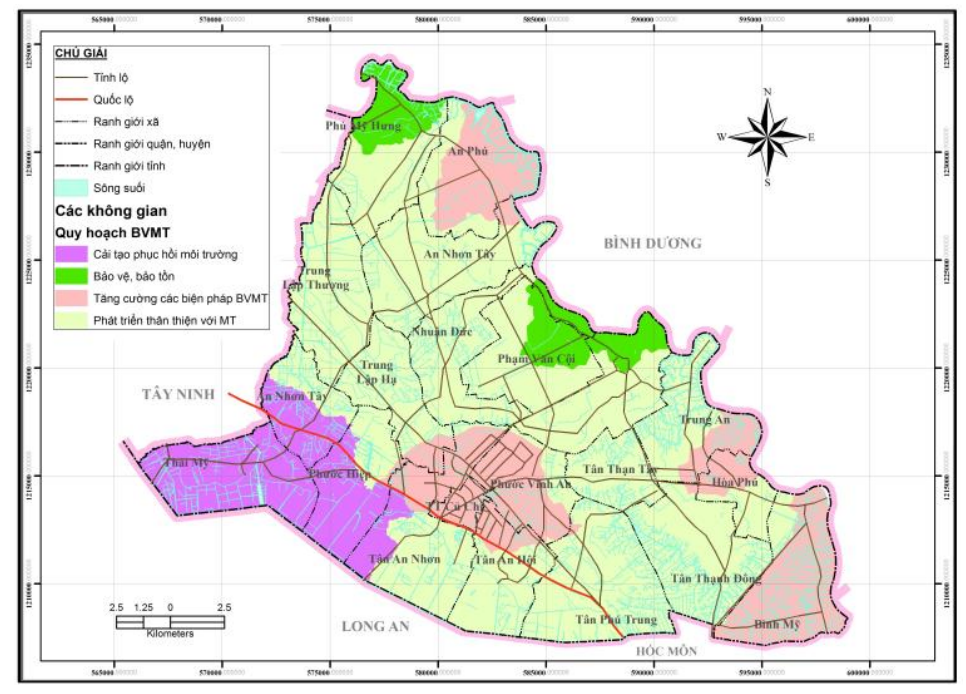

Hình 5. Không gian phát triển kinh tế - xã hội và bảo vệ môi trường huyện Củ Chi. 
c. Không gian tăng cường các biện pháp quản lý môi trường

Không gian tăng cường các biện pháp QLMT có diện tích 8.370.21ha chiếm 19,24\% diện tích toàn huyện. Phân bố tại các xã An Phú, Trung An, Hòa Phú, Bình Mỹ và thị trấn Củ Chi. Không gian này có 4 tiểu vùng bao gồm: Tiểu vùng An Phú (A.III); Tiểu vùng Trung An (B.II);

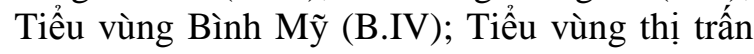
Củ Chi (B.V) (xem Hình 5).

Các chức năng chính: Là trung tâm hành chính, kinh tế, văn hoá, xã hội của huyện; phát triển mạnh các ngành công nghiệp, tiểu thủ công nghiệp, thương mại, dịch vụ du lịch; hạ tầng đô thị đồng bộ. Cung cấp không gian phát triển kinh tế - xã hội, không gian sống với chức năng hình thành khu dân cư và các khu du lịch sinh thái nhà vườn phục vụ DLST dọc sông Sài Gòn.

Định hướng không gian phát triển KT-XH và bảo vệ môi trường: Nâng cao nhận thức cộng đồng về bảo vệ môi trường. Quy hoạch hệ thống thu gom, vận chuyển và xử lý CTR; Quy hoạch khu vực cải tạo đất phát triển vườn cây ăn quả khu vực ven sông Sài Gòn, xây dựng hệ thống kè, cống để hạn chế nguy cơ ngập lụt (vùng ven sông). Triển khai đồ án quy hoạch khu nông nghiệp kết hợp du lịch sinh thái và dân cư nhà vườn. Xây dựng các bến thuyền phục vụ phát triển du lịch sinh thái theo tuyến dọc sông Sài Gòn.

$\mathrm{d}$. Không gian cải tạo và phục hồi môi trường

Nằm ở phía tây bắc huyện, có diện 5.087,24 ha thuộc địa bàn các xã Thái Mỹ, Phước Thạnh, Phước Hiệp, giáp địa giớ tỉnh Long An và Tây Ninh. Kinh tế chủ yếu là phát triển nông nghiệp với các nhóm cây trồng chính là lúa và hoa màu. Khu vực đã được xây dựng tổ hợp xử lý chất thải rắn Tây Bắc Củ Chi. Các vấn đề môi trường nổi cộm: Ố nhiễm do hoạt động của khu xử lý chất thải rắn tây bắc Củ Chi diện tích 822ha. Ô nhiễm do sản xuất công nghiệp ở khu công nghiệp Thái Mỹ (sát Tây Ninh), đất đai nhiễm phèn, úng cần được cải tạo (xem Hình 5).

Định hướng quy hoạch bảo vệ môi trường: trồng rừng phòng hộ kết hợp bảo vệ môi trường, tạo thành vành đai xanh xung quanh khu xử lý chất thải rắn Tây Bắc Củ Chi để hạn chế tác động đến các tiểu vùng đô thị phía Tây Bắc và các tiểu vùng môi trường xung quanh. Cải tạo đất xây dựng phát triển các mô hình kinh tế, trang trại cây ăn quả, kết hợp rừng phòng hộ.

\section{Kết luận}

Kết quả nghiên cứu đã phân chia huyện Củ Chi thành 3 vùng, 16 tiểu vùng môi trường, đồng thời đề xuất thành 4 không gian phát triển kinh tế - xã hội và bảo vệ môi trường sau: i) Không gian bảo vệ, bảo tồn: đã xác định được 2 tiểu vùng là $\mathrm{A} . \mathrm{I}$ và $\mathrm{A}$.V với diện tích $2.286,00$ ha chiếm 5,27\% tổng diện tích tự nhiên huyện; ii) Không gian tăng cường các biện pháp quản lý môi trường có diện tích là 8.370.21 chiếm 19,24 \% diện tích lãnh thổ; iii) Không gian phát triển thân thiện với môi trường có diện tích là $27.753,16$ ha chiếm $63,8 \%$ diện tích quy hoạch; iv) Không gian cải tạo và phục hồi môi trường là các khu vực đã bị xuống cấp và sẽ được cải tạo, chẳng hạn như những khu vực đã ngừng khai thác khoáng sản, khu vực thường xuyên chịu tác động mạnh của lũ, lụt và nước biển dâng hoặc những khu vực rừng tự nhiên bị chặt phá. Địa bàn huyện Củ Chi đã xác định được một không gian với diện tích 5.087,24 ha chiếm 11,69\% diện tích tự nhiên.

\section{Tài liệu tham khảo}

[1] Cu Chi District People's Committee, Report on landuse planning by 2020, Cu Chi District, 2015 (in Vietnamese).

[2] Nguyen Cao Huan, Spatial zoning for economic development, sustainable use of natural resources and environmental protection at district and province level - Case study in Lao Cai Province, Journal of Science, Hanoi National University, Special Issue in Natural Science and Technology 4(XX) (2004) 55-65 (in Vietnamese).

[3] The People Assembly of Vietnam, Environmental Protection Law, Hanoi, 2014 (in Vietnamese).

[4] Nguyen Huy Anh, Vu Van Luong, Sustainable integrated territorial management on the basis of environmental zoning in Phu Loc District, Thua 
Thien Hue Province, Hue University Journal of Science, Special issue on Earth and Environmental Science 120 (2016) 5-15 (in Vietnamese).

[5] Tran Thi Tuyet, Environmental zoning for territorial management of Mong Cai, Human Geography Review 1 (2014) 12-17 (in Vietnamese).

[6] Dang Van Loi, Study on the methodology of environmental zoning for sustainable development, Research final report, Ministry of Natural Resource and Environment, Hanoi, 2009 (in Vietnamese).
[7] Truong Quang Hai, Region as territorial unit for socio-economic development in Vietnam, Conference proceedings of scientific principles for regional development in Vietnam in the context of international integration, (2011) 21-28 (in Vietnamese).

[8] Dang Trung Thuan, Environmental planning in the context of development planning, Collection of selected scientific report for National Environment Congress, Hanoi, (2005) 238-244 (in Vietnamese). 